\title{
Loosening the Ties that Bind: Academic Librarians and Tenure
}

\author{
Jeanie M. Welch and Frada L. Mozenter
}

This article discusses the impact of faculty status and tenure on the professional lives of academic librarians. Included are a literature review, a discussion of the decline of tenure at academic institutions, and experiences at three universities. This article also includes the results of a survey that focused on the impact of faculty status and tenure on librarians' participation in institutional governance, opportunities for professional growth, and presence of a faculty library advisory committee. Based on the results of this survey, the authors conclude that only faculty status and tenure guarantee full integration in the university's governance and academic spheres.

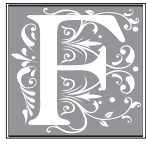

aculty status and eligibility for tenure for academic librarians have been discussed and debated for decades. Among the issues discussed and debated are the following: Do librarians "qualify" as college and university faculty, and to what extent should evaluation criteria take into account differences in duties and schedules? Does faculty status enhance librarians' professional identity on campus and thus provide for greater campus involvement? Does it just translate into additional burdens resulting in "an artificial force-fitting of activities into an inappropriate mold" and in "a fragmented profession, characterized in part by teaching, research-conducting, nonserving Ph.D.s who 'work' in a library'?"1 Should faculty status be no more than a "potential vehicle for the attainment of integration" where the real issue is "academic credibility" and not status? ${ }^{2}$ Does it mean that librarians, in accepting equal access to university governance, also must accept "the attendant responsibilities of publishing and professional leadership"? ${ }^{3}$ Does faculty status confer a benefit beyond the individual to the library, the profession, and the institution? ${ }^{4}$ Conversely, if faculty status and tenure are not available, are there any costs to the individual, the library, the profession, and the institution? If faculty status and tenure are not available, what professional and structural changes are required and how should these changes be implemented?

Part of the discussion may rest in defining terms. Tenure is defined "an institutional commitment to permanent and continuous employment to be terminated only for adequate cause (for example, incompetence; moral turpitude; retirement for reasons of age, mental or physical disability; bona fide financial exigency) and only after due process. Tenure (continuous appointment) shall be available to

Jeanie M. Welch is a Business Reference Librarian in Atkins Library at the University of North Carolina at Charlotte; e-mail: jmwelch@email.uncc.edu. Frada L. Mozenter is a Social Sciences Reference Librarian in Atkins Library at the University of North Carolina at Charlotte; e-mail: flmozent@email.uncc.edu. 
librarians in accordance with the tenure provision of all faculty of the institution.." ${ }^{5}$ Defining faculty status has proved more difficult. Janet Krompart used ALA's definition of "an official recognition by an institution of postsecondary education that librarians are part of the instructional and research staff by conferment of ranks and titles identical to those of faculty, and commensurate benefits, privileges, rights, and responsibilities." 6 The Association of Research and College Libraries (ACRL) defined faculty status as entailing "for librarians the same rights and responsibilities as for other members of the faculty," including "corresponding entitlement to rank, promotion, tenure, compensation, leaves, and research funds." ${ }^{7}$ In 1971, ACRL adopted the Guidelines for Academic Status for College and University Librarians; the guidelines were revised in 2002. Furthermore, the Board of ACRL stated its continued support for "faculty rank, status, and tenure for librarians." ${ }^{8}$ Shannon Cary reviewed the findings from ACRL's 1999 survey, Trends in Academic Libraries: Faculty Rank, Status, and Tenure for Librarians, and found these nine conditions as constituting faculty status. They included:

- Librarians are assigned professional responsibilities;

- Librarians have a governance structure similar to other faculties on campus;

- Librarians are eligible for membership in the faculty governing body;

- Librarians have salary scales that are equivalent to those for other academic faculty;

- Librarians are covered by the same tenure policies as other faculty;

- Librarians are promoted through the ranks via a peer review system;

- Librarians are eligible for leaves of absence or sabbaticals;

- Librarians have access to funding for research projects;

- Librarians have the same protections of academic freedom as other faculty. $^{9}$

\section{A Changing Reality}

Although this philosophical debate continues, the conditions affecting faculty status and tenure are evolving. For years, librarians have tried "to define their worth against a model that bears little resemblance to the ideal of the profession" ${ }^{10}$ and have often "fallen short in the comparisons." 11 Teaching faculty are dealing with a similar conceptual problem, mainly teaching versus scholarship and publication. Data on staffing patterns in higher education confirm that full-time, non-tenure-track appointments have been increasing whereas tenure-track positions are declining in all fields with the exception of business and engineering. ${ }^{12}$ Two U.S. Department of Education studies (1996 and 1998) reported that from 1975 to 1995 the proportion of full-time faculty on contracts climbed from 19 percent to 28 percent whereas those on tenure track fell from 29 percent to 20 percent. ${ }^{13}$ The Department also reported that more than one-half of all new full-time faculty at four-year institutions are non-tenure track. For example, Duke University has instituted a model called "professors of practice" for full-time, non-tenure-track faculty with renewable contracts. They are evaluated primarily on teaching and are not required to do the same type of research that the tenure-track faculty must do. This group makes up about 10 percent of Duke's faculty. Emory University also used this model for ninety positions. ${ }^{14}$

Some concerns and issues are strikingly similar to those faced by the library profession. Tenure is the "engine that drives the scholarly process." ${ }^{15}$ This is true for academic librarians as well as "teaching" faculty. However, tenure brings costs to the university in the form of higher salaries. These costs provide a "target of opportunity" [for] "cost-cutting."16 Moreover, tenure is the mechanism that safeguards academic freedom in both the form of scholarship and questioning administrative practices and policies. When Richard Moser, an associate secretary of the American Association of University 
Professors, stated that separating professors into ranks based on research versus teaching would lead to a plantation-style system, he was asked: "But what if all sides are happy with this arrangement?" His response serves both nonlibrary faculty and librarians. The concern should be "the health of the institutions overall." 17

One model of change for academic librarians is Susan Martin's “two-track approach to librarianship." The premise is that we must use performance levels that form the backbone of the profession as a basis of a new "self-definition" and professional restructuring. She detailed one approach as creating two distinct categories, with possible nomenclatures as "professional librarian" and "occupational librarian," allowing the individual to select the track appropriate for him- or herself. ${ }^{18}$

\section{A Tale of Three Academic Libraries}

As stated by Julie J. McGowan and Elizabeth H. Dow, "Because of perceived inequities on the part of both library and teaching faculty, a number of institutions even reversed their stand on faculty status for academic librarians and moved their librarians to a non-faculty, professional or administrative status." ${ }^{19}$ What are the realities when academic institutions change the professional status and eligibility for tenure of their librarians? This section includes a review of three academic libraries to reveal why such changes in professional status occurred, how they were handled, and the outcomes.

\section{The University of Oklahoma, Norman}

An excellent article by Pat Weaver-Meyers chronicled how faculty status and tenure were lost and then regained by librarians at the University of Oklahoma. ${ }^{20}$ Librarians at the University of Oklahoma received faculty status from the University Board of Regents in 1967. By the 1980s, all faculty members were under increasing pressure to publish and departmental criteria, for both tenure and promotion, became more exacting. Although publications by librarians were comparable with peers, in 1986, they were deemed unacceptable by a campuswide tenure committee at the time when two librarians were reviewed for tenure. In 1990, the University Program Review Committee issued a report, supported by the university president, stating that tenure was inappropriate for library positions. In 1991, the libraries' dean was directed to develop a plan incorporating nontenured "clinical faculty" appointments. New hires would be classified as nontenured or professional staff. Existing faculty could remain tenured, stay on the tenure track, or switch to the new classification. The plan was submitted in June 1991, with librarians choosing their status: ten selected non-tenure-track appointments and twelve remained tenured or on the tenure track. The following year seven new non-tenure-track appointments were made.

As this was occurring, a group of tenured library faculty members filed a complaint with the Faculty Senate. Subsequently, the Faculty Senate issued a report opposing consecutive-term appointments. The decision was based on a campuswide concern that this would weaken tenure and provide an opening for "many sorts of potential administrative abuse of the proposed type of faculty appointment." ${ }^{21}$ The university administration then charged the Faculty Senate with examining faculty status for librarians. The Ad Hoc Committee to Review Tenure within the University Libraries issued a report in 1993 that supported tenure for librarians. In August 1993, the university administration accepted the committee's report and provided the following options for librarians:

- Library faculty with non-tenuretrack appointments were permitted to change to tenure-track faculty appointments with allowances made for years employed under the prior status, or if the individual did not want to change tracks, the position would convert to a professional staff appointment. 
- Tenure-track library faculty who chose clinical faculty appointments were permitted to continue with their original tenure-track appointment or change to a professional staff appointment.

Through resignations and retirements, all positions eventually are to revert to tenure track.

\section{Virginia Polytechnic Institute and State University, Blacksburg}

An article by Edward F. Lener, Bruce Pencek, and Susan Ariew discussed faculty status for librarians at Virginia Tech. ${ }^{22}$ The general faculty at Virginia Tech included both "collegiate" (teaching) faculty and "extra-collegiate" library faculty. Extra-collegiate library faculty were eligible for "continued appointment" and promotion via a process that paralleled that of the teaching faculty but recognized differences in responsibilities. Recommendations for continued appointment and promotion were made by a University Promotion and Continued Appointment Committee for Extra-Collegiate Faculty. Extra-collegiate faculty were entitled to the protections of academic freedom and job security, and held academic ranks. Promotion and tenure polices for extracollegiate faculty were in a document developed by the Library Faculty Association (LFA) and the dean of libraries. The LFA was the formal representative body of the library faculty and included all librarians below the dean and associate dean.

In 2001, a university-level ad hoc committee recommended strengthening existing standards and establishing more consistent procedures throughout the campus. A directive from the provost was sent to all academic units, including the library, charging them to review their standards and "explicitly delineate appropriate measures or indicators of successful outcomes with respect to research, teaching, and outreach and to ensure fair and equitable treatment of all faculty." ${ }^{23}$ In February 2002, this charge was referred to the library's Faculty Affairs Committee (FAC), an elected, standing committee of the LFA. The FAC completed the following:

- Conducted an internal needs assessment;

- Compared local practices with other institutions in the state of Virginia and selected research universities;

- Provided progress reports to all librarians at monthly LFA meetings;

- Posted the initial draft on the LFA Web site;

- Held public forums;

- Revised the draft document based on input from the library faculty;

- Held two "readings" culminating in a final unanimous vote of approval.

The final document:

- Emphasized professional growth and the common good as goals of promotion and continued appointment;

- More clearly defined faculty ranks and professional;

- Made requirements for promotion to professor more rigorous;

- More clearly defined indicators of professional and scholarly achievement needed for promotion and continued appointment;

- Defined and emphasized research, professional experience, and scholarship and learning.

\section{The University of North Carolina at Charlotte}

Librarians at UNC Charlotte have had faculty status and eligibility for tenure since 1965. During the 2001-2002 academic year, the interim university librarian informed the library faculty that the tenure document need to be revised and requirements for reappointment, promotion, and tenure strengthened. The Library Review Committee of the Library Faculty began revising the tenure document after the arrival of the new university librarian in 2002. ${ }^{24}$ In February 2003, the university librarian called a special meeting of the twenty-nine-member library faculty to inform them that the reappointment and tenure applications of three library faculty members were being tabled. The 
interim provost was instituting a new status for library faculty under Special Faculty Appointments, as provided for in the university's tenure policy. [Faculty members hired under the special faculty appointments are hired under specified terms of service and are not eligible for permanent tenure. ${ }^{25}$ ] This new career track would consist of non-tenure-track, multiyear appointments. ${ }^{26}$ The rationale given for this change was the university's determination that librarians would not be able to meet the more exacting standards regarding reappointment, tenure, and promotion. The library administration did not state any opposition to this change.

There had been no consultation with the library faculty prior to this meeting. The Interim Provost and the university's General Counsel attended a meeting of the library faculty to discuss the university's decision, and a draft document entitled "Procedures for Initial Appointment, Reappointment, and Promotion for UNC Charlotte Librarians," was written. The draft document outlined proposed procedures and categorized librarians by library rank (e.g., general librarian) rather than by university rank (e.g., associate professor). ${ }^{27}$ Librarians would continue to have faculty status and participate in university governance. Librarians currently on tenure track or holding tenure would have the options of staying on tenure track, retaining tenure and going through the post-tenure review process, or resigning from their tenure-track or tenured positions and signing multiyear contracts as covered library faculty. A number of issues and concerns were raised at this meeting, including:

- Perceived lack of collegiality on the part of the university administration;

- The library faculty's role in contributing to the procedures document;

- Requirements and standards of teaching and scholarship, including the definition of teaching;

- Academic freedom;

- Promotion;

- Participation in university governance. $^{28}$
The library faculty was split over the issue of a new career path. In university governance, the library had been considered a separate college and the university librarian had status equivalent to a dean. It was the first time that the university's Special Faculty Appointments designation had been implemented for an entire college. Some librarians accepted the new career track; others, both tenured and those on the tenure track, felt betrayed. In addition, there was pressure to approve the new procedures document so that candidates for library faculty positions would have access to the new procedures during their interviews. Several special meetings, including another meeting with the interim provost, were held to revise the new procedures document, revise the previous tenure document, and to implement such changes as parallel library faculty committees for covered and tenure-track faculty appointment, reappointment, and promotion. The new procedures document for covered library faculty was approved in March 2004..$^{29}$

As early as April 2003, a librarian on the University Faculty Executive Committee brought the new career track to the university faculty's attention. ${ }^{30}$ During the 2003-2004 academic year this issue was discussed at several meetings. ${ }^{31}$ Eventually the Faculty Employment Status Committee (FESC) was charged with investigating this situation and reporting to the Faculty Executive Committee. The FESC met with the associate provost, the university general counsel, and the university librarian. ${ }^{32}$ The FESC made the following recommendations to the Faculty Executive Committee:

- Give the library faculty a deadline for making a decision about switching to the Special Faculty Appointments track only after the new operational procedures are in place;

- The library faculty should be given the opportunity to be actively involved in developing the new operational procedures. ${ }^{33}$ 
The Faculty Executive Committee accepted the recommendations of the FESC. In addition, the committee charged the FESC to "obtain and analyze information regarding the issue of tenure-track, nontenure-track, and part-time faculty." 34

For the library faculty, the implementation of the new career path has meant having two career tracts, tenure track and covered library faculty (non-tenure track). As a result, one librarian on tenure track was awarded tenure, two left university employment, and the remainder chose the new career path. For those librarians who already had tenure, all but one chose to retain tenured status. All new hires since implementation of the new career path have been covered library faculty.

\section{Summary}

Why were the outcomes so different among these three institutions? At the University of Oklahoma, the librarians were successful because they had strong support from the Faculty Senate, which viewed the issue as one of administration usurping faculty rights. In response to a forceful and united stand by the Faculty Senate, the administration developed creative and flexible alternatives. At Virginia Polytechnic, the university's charge was referred to the library's Faculty Affairs Committee, an elected, standing committee of the LFA, the formal representative body of the library faculty. The library faculty had input throughout the process including a final vote. At the University of North Carolina at Charlotte, there was no prior consultation or discussion with the library faculty nor was there any formal statement of support for retaining eligibility for tenure by the library administration or the teaching faculty.

\section{Do Tenure and Faculty Status Matter? Results of a Selective Survey}

In light of the experiences on these campuses, the question may be raised whether faculty status and tenure for academic librarians have a meaningful impact on working conditions, professional careers, and the library as an institution. Do they confer "a benefit beyond the individual" ? ${ }^{35}$ Do they aid in the attraction and retention of librarians? Do they make a better library? Do they make a better institution? Does this type of collegiality increase the librarian's (and thus the library's) impact on the institution? Does it advance the goals of the library? Does it make university committee membership more meaningful by making librarians' opinions and concerns more valid? ${ }^{36}$ A number of surveys speak to this question and have addressed the following topics:

- Satisfaction with faculty status, based on type of institution, academic rank, promotion history, primary area of responsibility, years of experience, tenure status, and gender;

- Differences with regard to library governance structure;

- Differences in eligibility for membership in the faculty governing body;

- Effects on salary scales;

- Differences in promotion policies;

- Differences in obtaining leaves of absence or sabbaticals;

- Differences in funding opportunities for research projects;

- Differences in academic freedom;

- Examined library faculty participation in governance. ${ }^{37}$

As a result of the developments regarding tenure for library faculty at UNC Charlotte, two members of the library faculty did a literature review to try to determine if faculty status and tenure made a difference in librarians' professional lives. In the course of their literature review, they found a comprehensive article on faculty status by Rachel Applegate that suggested that: "Researchers could look further than the question of whether faculty status increases collegiality to whether it increases librarians' impact on institutional governance." ${ }^{38}$ This statement reflects this standard of the ACRL Standards for Faculty Status for College and University Librarians: 
3. College and university governance-Librarians should be eligible for membership in the faculty senate or equivalent government body. They should have the same degree of representation as other academic units on all college or university governing bodies. ${ }^{39}$

The investigating librarians also were interested in the impact of faculty status and tenure on librarians' participation in opportunities for professional development. These issues are included in the following ACRL Standards for Faculty Status for College and University Librarians:

\section{Promotion-Librarians should be promoted in rank based on their academic proficiency and profes- sional effectiveness.}

\section{Leaves-Sabbatical and other} research leaves should be available to librarians consistent with standards. ${ }^{40}$

The research hypothesis for the study was to ascertain whether there was any statistically significant evidence of a relationship between faculty status and eligibility for tenure and academic librarians being eligible for the following:

- Promotion

- University or professional ranks

- Release time for sabbaticals or research

- Travel funds

- Service on campuswide committees

- Voting privileges within campuswide committees

- Service on the campus faculty senate or other campuswide governing body

- Voting privileges within the Faculty Senate

An additional research hypothesis was to test whether there was any statistically significant evidence of a relationship between faculty status and eligibility for tenure for academic librarians and the presence of a faculty library advisory committee.

In spring 2003, the investigating librarians sent surveys to the heads of public services or reference services at a hundred libraries classified as Doctoral/Research Universities-Intensive by the Carnegie Foundation for the Advancement of Teaching in the year 2000. ${ }^{41}$ Both private and public institutions were included. The questionnaire is shown in appendix A. Respondents were offered copies of the preliminary results upon request. Fifty-five out of 100 questionnaires were returned; all returned questionnaires were deemed usable. Questionnaires were returned by librarians at 32 public universities and 23 private universities. The response rate was 55 percent; such a response rate is considered to be average for an academic study. ${ }^{42}$ Additional comments were generally of an explanatory nature. Twelve respondents requested copies of the preliminary results.

Preliminary analysis of the responses indicated the following results:

- Over 70 percent of responding librarians reported having faculty status on their campus.

- Less than 50 percent were eligible for tenure.

- Very few libraries had two-track systems for librarians (i.e., both tenuretrack and non-tenure-track faculty).

- Less than 50 percent reported librarians holding university ranks (e.g., professor).

- Over 60 percent reported eligibility for release time for research.

- Over 95 percent reported eligibility for travel funds.

- Over 85 percent reported eligibility to serve on campuswide committees with voting privileges.

- Over 75 percent reported eligibility to serve on the campuswide governing body (i.e., Faculty Senate), although fewer had voting privileges.

- Eighty percent reported having a library faculty advisory committee. 
Table 1 summarizes all responses, including the number of responses and the percentages responding yes or no to the survey questions.

When the responses were divided on the basis of professional status, the percentages changed in some instances. Table 2 represents the percentage of affirmative responses from libraries, differentiated by professional status (nonfaculty status, faculty status, tenure track), with the exception of responses from libraries having a two-track system.

A cursory examination of table 2 demonstrates that faculty status and eligibility for tenure increased the probability of academic librarians' participation in faculty governance and some opportunities for professional growth. Eligibility for tenure meant affirmative answers in all categories related to professional growth and participation in institutional governance. The responses to the questions concerning university rank or professional rank seem contradictory. Although all responses from libraries with tenure track reported that librarians had university rank (e.g., professor), 55.6 percent also responded that librarians had professional rank (e.g., assistant librarian). This seeming contradiction may be due to libraries having a dual system of titles for university and professional ranking (e.g., professor and associate librarian).

Although these tables may provide useful data for comparison, the investigating librarians wanted to determine if there was statistically significant evidence of relationships among professional status and eligibility for tenure, participation in campus governance, and opportunities for professional growth. The SPSS CROSSTAB program (version 12.0) was employed. Results were deemed to be statistically significant evidence of a relationship if the Pearson's correlation $(r)$ had an approximate significance of $p<.05$ for the two variables of faculty status and

\begin{tabular}{|c|c|c|}
\hline \multicolumn{3}{|l|}{$\begin{array}{c}\text { TABLE 1 } \\
\text { All Responses }\end{array}$} \\
\hline Question (number of responses) & $\begin{array}{l}\text { Percentage } \\
\text { Yes }\end{array}$ & $\begin{array}{l}\text { Percentage } \\
\quad \text { No }\end{array}$ \\
\hline Library has both tenure and non-tenure tracks $(\mathrm{n}=55)$ & 13 & 87 \\
\hline Librarians have faculty status $(\mathrm{n}=54)$ & 72.2 & 27.7 \\
\hline Librarians eligible for tenure $(\mathrm{n}=55)^{1,2}$ & 42.6 & 55.6 \\
\hline Librarians eligible for promotion $(n=54)^{2}$ & 75.5 & 22.2 \\
\hline Librarians hold university ranks (e.g., professor) $(\mathrm{n}=55)^{2}$ & 35.2 & 63.0 \\
\hline $\begin{array}{l}\text { Librarians hold library/professional ranks (e.g., associate } \\
\text { librarian }(\mathrm{n}=38)\end{array}$ & 47.5 & 50.0 \\
\hline Librarians eligible for sabbaticals/release time $(n=53)$ & 60.4 & 39.6 \\
\hline Librarians eligible for travel funds $(n=53)$ & 96.2 & 3.7 \\
\hline Librarians eligible to serve on campuswide committees $(n=53)$ & 86.5 & 13.5 \\
\hline Librarians have voting privileges $(n=46)^{3}$ & 95.7 & 4.3 \\
\hline Librarians eligible to serve in faculty senate $(\mathrm{n}=53)$ & 78.8 & 21.2 \\
\hline Librarians have voting privileges $(n=40)^{3}$ & 100 & 0 \\
\hline Library has a faculty advisory committee $(n=51)$ & 80.0 & 20.0 \\
\hline \multicolumn{3}{|c|}{$\begin{array}{l}{ }^{1} \text { Percentages do not include libraries reporting both tenure and non-tenure tracks. } \\
{ }^{2} \text { Percentages do not include responses other than yes/no. } \\
{ }^{3} \text { Based on those responding to previous question. }\end{array}$} \\
\hline
\end{tabular}




\begin{tabular}{|c|c|c|c|}
\hline \multicolumn{4}{|c|}{$\begin{array}{c}\text { TABLE } 2 \\
\text { Responses by Professional Status }\end{array}$} \\
\hline "Question & $\begin{array}{c}\text { Percentage } \\
\text { without } \\
\text { Faculty Status }\end{array}$ & $\begin{array}{c}\text { Percentage } \\
\text { with Faculty } \\
\text { Status }\end{array}$ & $\begin{array}{c}\text { Percentage } \\
\text { with } \\
\text { Eligibility } \\
\text { for Tenure }\end{array}$ \\
\hline Librarians have faculty status. & - & 72.22 & 100 \\
\hline Librarians are eligible for tenure. ${ }^{1}$ & 0 & 59.0 & - \\
\hline Librarians are eligible for promotion. ${ }^{1}$ & 53.3 & 84.2 & 100 \\
\hline Librarians hold university ranks. ${ }^{1}$ & 0 & 48.7 & 73.9 \\
\hline $\begin{array}{l}\text { Librarians hold library/professional } \\
\text { ranks. }{ }^{1}\end{array}$ & 40.0 & 52.2 & 55.6 \\
\hline $\begin{array}{l}\text { Librarians are eligible for sabbaticals or } \\
\text { release time for research. }\end{array}$ & 13.3 & 78.9 & 100 \\
\hline Librarians are eligible for travel funds. & 92.2 & 97.4 & 100 \\
\hline $\begin{array}{l}\text { Librarians are eligible to serve on cam- } \\
\text { pus committees. }\end{array}$ & 61.5 & 94.5 & 100 \\
\hline Librarians have voting privileges. $^{2}$ & 87.5 & 97.4 & 100 \\
\hline $\begin{array}{l}\text { Librarians eligible to serve in faculty } \\
\text { senate. }\end{array}$ & 35.7 & 94.7 & 100 \\
\hline Librarians have voting privileges. $^{2}$ & 100 & 100 & 100 \\
\hline Library has a faculty advisory committee. & 71.4 & 82.9 & 85.0 \\
\hline
\end{tabular}

eligibility for tenure. Table 3 shows the Pearson's correlation value $(r)$ and the approximate significance $(p)$ of faculty status and eligibility for tenure for each question with the exception of responses from libraries having a two-track system.

Table 3 shows statistically significant evidence of a relationship between faculty status and the following:

- Eligibility for tenure;

- Holding university rank;

- Eligibility for sabbaticals or release time for research;

- Eligibility to serve and vote on campuswide committees;

- Eligibility to serve and vote in the faculty senate.

Table 3 also shows statistically significant evidence of a relationship between eligibility for tenure and eligibility for promotion and between faculty status and eligibility for tenure.

\section{Conclusion}

As academic librarians enter this period where roles are redefined and status is challenged for all faculty, they will need to work with library and university administrations to develop new accommodations. The definition of teaching will have to be examined along with the criteria to be used for teaching, research/scholarship, publication, and job performance. ${ }^{43}$ For those outside the library, what may be needed is an "understanding of librarianship, coupled with a significant appreciation of analogs and dissimilarities between teaching and librarianship." ${ }^{44}$ Also, so as not to have to "disguise" what librarians do, "it is necessary for librarians to understand enough of the functions and circumstances of non-librarian faculty so that librarianship and accomplishments of individual librarians can be described in terms that 
teaching faculty will understand, that draw appropriate parallels, and that treat differences clearly but without apology." ${ }^{45}$ According to Richard Slattery, "At issue is whether academic librarians 'qualify' as college and university faculty, and to what extent performance criteria should take into account differences in 'duties and schedules' between librarians and teaching faculty." ${ }^{46}$

Also according to Slattery, "To opponents the pursuit by academic librarians of a status identical to that of teaching faculty is unrewarding, unwise, and potentially destructive. Acceptance of the faculty model means an additional, 'unnecessary burden which results in an artificial forcefitting of activities into an inappropriate mold.'" ${ }^{47}$ Also according to Slattery, "To its proponents, faculty status is an appropriate complement to our sense of professional identity. It is the passport to greater campus involvement and to enhanced self-esteem and prestige, and is the instrument that allows us to more accurately gauge the quality and variety of services required of us." ${ }^{48}$ When university and library administrators move away from this system, these issues and concerns may arise:

- There may be less of a university commitment to the individual;

- Academic librarians may be in a less favorable position in regard to pay, leave, and professional development;

- Academic librarians may be more easily replaced by cheaper labor;

- There may be less publishing and scholarship to the detriment of the profession;

- There may be an impact on job satisfaction and turnover rates;

- Academic freedom and dissent may be stifled.

Concerns about the aforementioned issues, in addition to the data obtained from the selective survey, may indicate that there are three primary reasons to continue to address the issues of faculty

\begin{tabular}{|l|c|c|c|c|}
\hline \multicolumn{5}{|c|}{$\begin{array}{c}\text { TABLE 3 } \\
\text { Summary of Pearson's Correlations (Pearson's R) Values } \\
\text { Significance of Faculty Status and Eligibility for Tenure }\end{array}$} \\
\hline \hline \multirow{2}{*}{\begin{tabular}{c} 
Huestion \\
\hline
\end{tabular}} & $\begin{array}{c}\text { Have Faculty } \\
\text { Status }\end{array}$ & \multicolumn{2}{c|}{$\begin{array}{c}\text { Eligible for } \\
\text { Tenure }\end{array}$} \\
\hline Librarians are eligible for tenure. & r & p & r & p \\
\hline Librarians are eligible for promotion. & .479 & $.000^{*}$ & - & - \\
\hline Librarians hold university ranks. & .264 & .056 & .550 & $.000^{*}$ \\
\hline Librarians hold library/professional ranks. & .406 & $.002^{*}$ & .737 & $.000^{*}$ \\
\hline $\begin{array}{l}\text { Librarians are eligible for sabbaticals or } \\
\text { release time for research. }\end{array}$ & .070 & .677 & .249 & .132 \\
\hline Librarians are eligible for travel funds. & .104 & $.000^{*}$ & .615 & $.000^{*}$ \\
\hline $\begin{array}{l}\text { Librarians are eligible to serve on } \\
\text { campus committees. }\end{array}$ & .423 & $.002^{*}$ & .330 & $.016^{*}$ \\
\hline Librarians have voting privileges. & .183 & .222 & .188 & .210 \\
\hline Librarians are eligible to serve in faculty senate. & .641 & $.000^{*}$ & .424 & $.002^{*}$ \\
\hline Librarians have voting privileges. & - & - & - & - \\
\hline Librarians have faculty status. & - & - & .479 & $.000^{*}$ \\
\hline Library has a faculty advisory committee. & .128 & .380 & .076 & .599 \\
\hline *Significant at the p<.05 level. & & & & \\
\hline
\end{tabular}


status and tenure for academic librarians: (1) full participation in university governance, enhancing the library's role in the academe; (2) academic freedom; and (3) full opportunity for professional growth. Taking into consideration the results of the selective study indicated that only tenure ensures all three.

\section{APPENDIX A \\ Librarians \& Institutional Impact Questionnaire}

1. 1 Are librarians split between two different systems, e.g., tenure track and yearly contracts?

a Yes a No

If you answered yes, please use the back of the questionnaire to explain the structure. Please answer as many of the following questions as possible.

2. Are librarians at your library eligible for tenure? Yes $\square$ No

If you answered no, what type of contracts do librarians have at your library? (Please use back of questionnaire.)

3. Are librarians at your library eligible for promotion? $\square$ Yes $\square$ No

4a. Do librarians at your library have university ranks of assistant professor, associate professor, full professor? $\square$ Yes $\square$ No

If yes, please go to question $\# 5$, if no, please go to question $\# 4 \mathrm{~b}$.

4b. If you answered no, do librarians at your library have the library/professional ranks of assistant librarian, associate librarian, full librarian or similar titles? $\square$ Yes $\square$ No

5. If you answered yes to question $4 b$., what titles does your library have? (e.g., Librarian I, junior librarian)?

6. Are librarians at your library eligible for sabbaticals or release time for research?

a Yes $\square$ No

7. Are librarians at your library eligible for travel funds? Yes $\square$ No

8. Are librarians at your library eligible to serve on campus-wide faculty committees (e.g., curriculum committees, grants committees, employment status committees)? $\square$ Yes $\square$ No

If you answered yes, do they have voting status? Y Yes $\square$ No

9. Are librarians at your library eligible to serve on the campus-wide faculty governing body (e.g., faculty senate or faculty council)? $\square$ Yes $\square$ No

If you answered yes, do they have voting status? Y Yes $\square$ No

10. Do librarians at your library have faculty status? Yes $\square$ No 1

If yes, please define what "faculty status" means at your library. 1

11. Is there a faculty advisory committee or group for your library? $\square$ Yes $\square$ No

If you have any additional comments on the status of librarians at your library and its impact on your institution, please use the back of this questionnaire.

Thank you for completing this survey. 


\section{Notes}

1. Charles E. Slattery, "Faculty Status: Another 100 Years of Dialogue? Lessons from the Library School Closings," Journal of Academic Librarianship 20 (Sept. 1994): 193.

2. Ibid., 196.

3. Rodney M. Hersberger, "The Challenges of Leading and Managing Faculty Status Librarians," Journal of Academic Librarianship 14 (Jan. 1989): 362.

4. Rachel Applegate, "Deconstructing Faculty Status: Research and Assumptions," Journal of Academic Librarianship 19 (July 1993): 161.

5. Model Statement of Criteria and Procedures for Appointment, Promotion in Academic Rank, and Tenure for College and University Librarians (Chicago: ACRL, 1987). Available online at http://www. ala.org/ala/acrl/acrlstandards/modelstatementcriteria.htm. For a proposed revision of the model statement, see "A Guideline for the Appointment, Promotion, and Tenure of Academic Librarians: A Draft," College \& Research Libraries News 66 (Apr. 2005): 308-15.

6. Janet Krompart, "Researching Faculty Status: A Selective Annotated Bibliography," College $\mathcal{E}$ Research Libraries 53 (Sept. 1992): 441.

7. Joint Statement on Faculty Status of College and University Librarians (Chicago: ACRL, 1972). Available online at http://www.ala.org/ala/acrl/acrlstandards/jointstatementfaculty.htm.

8. Guidelines for Academic Status for College and University Librarians (Chicago: ACRL, 2002). Available online at http://www.ala.org/ala/acrl/acrlstandards/guidelinesacademic.htm.

9. Shannon Cary, "Faculty Rank, Status, and Tenure for Librarians," College \& Research Library News 62 (May 2001): 510-11.

10. Julie J. McGowan and Elizabeth H. Dow, "Faculty Status and Academic Librarianship: Transformation to a Clinical Model," Journal of Academic Librarianship 21 (Sept. 1995): 345.

11. Ibid.

12. Roger G. Baldwin and Jay L. Chronister, Teaching without Tenure: Policies and Practices for a New Era (Baltimore: The Johns Hopkins Univ. Pr., 2001), 3.

13. Courtney Leatherman, "Growth in Positions off the Tenure Track Is a Trend That's Here to Stay, Study Finds," Chronicle of Higher Education 45 (Apr. 9, 1999): A14.

14. Piper Fogg, "For These Professors, 'Practice Is Perfect,'" Chronicle of Higher Education 50 (Apr. 16, 2004): A12-A14.

15. Richard W. Meyer, "Surviving the Change: The Economic Paradigm of Higher Education in Transformation," Journal of Academic Librarianship 23 (Jul. 1997): 296.

16. Ibid.

17. Fogg, "For These Professors, 'Practice Is Perfect,'” A14.

18. Susan Martin, "Raising Our Professional Expectations with a Two-Track Approach to Librarianship," Journal of Academic Librarianship 19 (Mar. 1993): 24.

19. McGowan and Dow, "Faculty Status and Academic Librarianship," 346.

20. Pat Weaver-Meyers, "Conflict Resolution: A Case Study about Academic Librarians and Faculty Status," College \& Research Libraries 63 (Jan. 2002): 25-34.

21. Ibid., 28.

22. Edward F. Lener, Bruce Pencek, and Susan Ariew, "Raising the Bar: An Approach to Reviewing and Revising Standards for Professional Achievement for Library Faculty," College $\mathcal{E}$ Research Libraries 65 (July 2004): 287-97.

23. Ibid., 291.

24. Library faculty minutes, University of North Carolina at Charlotte, Feb. 18, 2003.

25. "Tenure Policies, Regulations, and Procedures of the University of North Carolina at Charlotte" (Unpublished document, University of North Carolina at Charlotte, July 1, 2004. Available online at http://www.legal.uncc.edu/tenurepol.html.

26. "Procedures for Initial Appointment, Reappointment, and Promotion for Covered Library Faculty at The University of North Carolina at Charlotte" (Unpublished document, University of North Carolina at Charlotte, 2004).

27. "Procedures for Initial Appointment, Reappointment, and Promotion for UNC Charlotte Librarians" (Unpublished document, University of North Carolina at Charlotte, 2003).

28. Library faculty minutes, University of North Carolina at Charlotte, Apr. 15, 2003.

29. Dawn Hubbs, e-mail message to library faculty, March 5, 2004.

30. Minutes of the Faculty Executive Committee meeting, University of North Carolina, Apr. 3, 2003.

31. Minutes of the general faculty meeting, University of North Carolina at Charlotte, Aug. 19, 2003.

32. Minutes of the Faculty Executive Committee, University of North Carolina at Charlotte, Oct. 2-9, 2003.

33. "Majority Recommendations on the Special Faculty Appointments in the Library" (Unpublished document, University of North Carolina at Charlotte Faculty Employment Status Committee, Mar. 3, 2004). 
34. Minutes of the Faculty Executive Committee, University of North Carolina at Charlotte, Mar. 4, 2004.

35. Applegate, "Deconstructing Faculty Status," 161.

36. Ibid.

37. See Marjorie A. Benedict, "Librarians' Satisfaction with Faculty Status," College E Research Libraries 52 (Nov. 1991): 538-48; Cary. "Faculty Rank, Status, and Tenure for Librarians," 510-511, 520; Page Ackerman, "Governance and Academic Libraries," Library Research 2 (1980-81): 11-12; Ronald F. Dow, "Academic Librarians: A Survey of Benefits and Responsibilities," College E Research Libraries 38 (May 1977): 218-20.

38. Applegate, "Deconstructing Faculty Status," 162.

39. Standards for Faculty Status for College and University Librarians (Chicago: ACRL, 2001). Available online at http://www.ala.org/ala/acrl/acrlstandards/standardsfaculty.htm.

40. Ibid.

41. Carnegie Foundation for the Advancement of Teaching, "Doctoral/Research Universities-Intensive," in Carnegie Classification of Institutions of Higher Education, 2000 edition (Menlo Park, Calif.: Carnegie Foundation for the Advancement of Teaching, 2000). Available online at http://www.carnegiefoundation.org/Classification/CIHE2000/PartIfiles/DRU-INT.htm.

42. Yahuda Baruch, "Response Rate in Academic Studies: A Comparative Analysis," Human Relations 52, no. 4 (1999): 429.

43. McGowan and Dow, "Faculty Status and Academic Librarianship," 346.

44. Janet Swan Hill, "Wearing Our Own Clothes: Librarians as Faculty," Journal of Academic Librarianship 20 (May 1994): 71.

45. Ibid.

46. Slattery, "Faculty Status," 193.

47. Ibid.

48. Ibid.; Elizabeth C. Henry, Dana M. Caudle, and Paula Sullenger, "Tenure and Turnover in Academic Libraries," College E Research Libraries 55 (Sept. 1994): 429-35; Patrick I. Nestor and Paul Leary, "The Relationship between Tenure and Non-Tenure Track Status of Extension Faculty and Job Satisfaction," Journal of Extension 38 (Aug. 2000). Available online at http://www.joe. org/joe/2000august/rb1.html. 